\title{
Proximate and amino acid composition of seeds of Canavalia ensiformis. Toxicity of the kernel fraction for chicks
}

\author{
A. Leon 1, I. Angulo 1, M. Picard 2*, B. Carré 2 , L. Derouet 2 \\ and J.P. Harscoat 2 \\ 1 Instituto de Investigaciones Zootecnicas, CENIAP-FONAIAP - Apdo 4653, Maracay, Venezuela \\ 2 Station de recherches avicoles, INRA, centre de Tours-Nouzilly, 37380 Monnaie, France
}

(reçu le 6 juillet 1989, accepté le 10 septembre 1989)

Summary - A proximate analysis of Canavalia ensiformis seeds (CE) appears to be very similar to that of Faba bean seeds. The crude protein content (31.3\% dry matter, DM) of CE should be corrected for its content of a non-nutritional amino acid, canavanin (3.6\% DM). The usable nitrogen sources in CE represent approximately $24 \%$ DM. CE has relatively low content of lysine as compared to other legume seeds. Starch ( $35.7 \% \mathrm{DM}$ ) is the main source of energy. Whole seeds contain $20.1 \% \mathrm{DM}$ of water-insoluble cell wall and 1.6\% DM of water-soluble non-starch polysaccharides. About half of these 2 fibre fractions come from the testa. Condensed tannins are only present as traces in CE. The effects of testa and kernel fractions and whole seed, equivalent to $30 \%$ CE in nutritionally balanced diets, were measured on food intake and growth reactions of 1 day-old and 15-22 day old chicks. Testa appeared to be devoid of sizeable toxic activity under the present conditions, while kernel and whole seed strongly depressed both parameters: growth was stopped and food intake was decreased by $70 \%$. An early food intake reaction (less than $4 \mathrm{~h}$ ) of the birds was noted and suggested to be an interesting signal of the toxicity of CE.

Canavalia ensiformis - jackbean - leguminosa - chemical composition - amino acid profile - toxicity - chick

Résumé - Composition et teneur en acides aminés des graines de Canavalia ensiformis. Toxicité des cotylédons de la graine pour les poussins. La composition chimique globale des graines de Canavalia ensiformis (CE) semble voisine de celle des graines de féveroles. La concentration en protéine brute $(31,3 \%$ matière sèche, MS) de CE devrait être corrigée pour tenir compte de la teneur élevée de CE en canavanine, un acide aminé sans valeur nutritionnelle $(3,6 \% M S)$. Les matières azotées utilisables par l'animal de CE représentent environ 24\% MS. La concentration en lysine est relativement plus faible que celle d'autres légumineuses. L'amidon (35,7\% MS) est la principale source d'énergie. Les graines entières contiennent $20,1 \%$ MS de parois végétales insolubles dans l'eau et $1,6 \%$ MS de polysaccharides hydrosolubles non amylacés. Au moins la moitié de ces 2 types de fibres se trouvent dans les enveloppes. Les graines de CE contiennent seulement des traces de tannins condensés. Les effets des enveloppes, des cotyledons et des graines entières à des concentrations équivalant à $30 \%$ de $C E$ dans des régimes équilibrés, sur lingéré alimentaire et la croissance des poussins de $1 j$ et entre 15 et $22 j$, ont été mesurés. Les enveloppes n'ont pas révélé d'action toxique mesurable dans nos conditions. Les régimes contenant les cotylédons ou les graines entières on fait fortement diminuer lingéré alimentaire (de $70 \%$ ) et la croissance (qui devient négative) des poussins. On a noté une réaction très précoce des poussins sur l'ingéré alimentaire (moins de $4 h$ ) qui pourrait être utilisée comme critère de mesure des effets toxiques de CE. Canavalia ensiformis - légumineuse - composition chimique - acide aminé - toxicité -
poussin

\footnotetext{
* Author to whom correspondence should be addressed.
} 


\section{INTRODUCTION}

Owing to its high nutritive value, soya bean meal is usually the main concentrated protein source for poultry feeds. However, because soya is not suited to a variety of climates and soils, scientists and agronomists continue to search for other sources of protein. There has been little development of suitable legume species in tropical climates. Canavalia ensiformis is a leguminosa adapted to a wide range of environmental conditions and represents hope for Venezuela at the present time. $C$. ensiformis belongs to the family Leguminosae and subfamily Papilionoidae and is cultivated in humid tropical areas in Asia, Africa and Latin America. Various aspects of agronomy and usage in animal feeds have been reviewed by Dixon et al. (1983). A major problem with $C$. ensiformis relates to its high content of some antinutritional factors such as concanavalin $A$, canavanin and trypsin inhibitors, which strongly reduce chicken growth (D'Mello et al., 1985).

The potential of this legume to produce both seeds and forage of high protein content is widely accepted. The ability of this plant to produce relatively high yields of seeds under adverse climatic and soil conditions has raised interest in this crop. However, complete data on the proximate composition of the seed are still lacking. The purpose of this work was to develop a detailed chemical characterization of the whole seeds of $C$. ensiformis, together with the analysis of kernel and testa of the seed. Being a potential source of protein, the amino acid content of the whole seed has also been determined. One of the simplest technological methods for detoxification would be to cut the testa off and use the kernel. Therefore, both fractions were tested separately for acceptability to chickens.
MATERIAL AND METHODS

\section{Analytical procedures}

A sample of Canavalia bean seeds was provided by the School of Agriculture of the Universidad Central de Venezuela in Maracay. Twenty seeds were hand-dissected in order to determine the relative proportions of testa and kernel. Both testa and kernel fractions were separately ground to $0.5 \mathrm{~mm}$ mesh-size before being analysed. Another sample of whole seed from the same batch was similarly ground for amino acid analyses.

Dry matter content was obtained by heating the samples at $103 \pm 1^{\circ} \mathrm{C}$ for $4 \mathrm{~h}$. Nitrogen was determined by the Kjeldahl procedure. Ash content was measured by incineration at $550^{\circ} \mathrm{C}$ for $16 \mathrm{~h}$. The Folch method (1957) was applied for lipid determination with a previous acidification $(6 \mathrm{~N}$ hydrochloric acid, $\mathrm{HCl}$ ), as suggested by Hakansson (1974) before chloroform-methanol extraction. Lipids were then purified by benzene extraction (Delpech et al., 1966) before being weighed. Starch was measured using the amyloglucosidase-dimethyl sulfoxide procedure (Boehringer Mannheim, 1980) as described by Carré et al. (1987).

The water-insoluble cell wall materials (WICW) were prepared by pronase and $\alpha$ amylase treatments, as described by Carré et al. (1984). Water-soluble non-starch polysaccharides were isolated from supernatant fractions of pronase and $\alpha$-amylase treatments by ethanolic $(80 \%)$ precipitation. Gas chromatography was used to measure their derivatized individual neutral sugars, according to the method of Blakeney et al. (1983). Colorimetry (m-phenylphenol) (Blumenkrantz \& Asbole-Hansen, 1973) allowed the determination of their uronic acids.

Sucrose was extracted by refluxing a $1.5 \mathrm{~g}$ sample in $25 \mathrm{ml}$ ethanol-water $(80: 20, \mathrm{v} / \mathrm{v})$ for $1 \mathrm{~h}$. Alcohol was eliminated from the extract with a rotary evaporator. After suspension in distilled water and fittration, sucrose was measured using the $\beta$-fructosidase/hexokinase/glucose 6phosphate dehydrogenase/NADP system (Bergmeyer \& Bernt, 1974) (Boehringer Mannheim Cat $\mathrm{N}^{\circ} 139041$ ). 
Amino acid determination was made on 4 replicated samples. Hydrolysis of protein was performed in $6 \mathrm{~N} \mathrm{HCl}$ at $110^{\circ} \mathrm{C}$ for $24 \mathrm{~h}$. For sulfur- containing amino acids (SAA), performic oxidation was followed by a 24-h hydrolysis. Amino acid chromatography was performed using a LKB 4400 amino acid analyser.

Condensed tanins were determined in waterinsoluble cell-walls by measuring anthocyanidins produced by treatment with hot $0.5 \mathrm{M} \mathrm{HCl}$ in butanol, as described by Carré and Brillouet (1986).

\section{Chick toxicity trial}

\section{Diets}

Seeds of the same batch of Canavalia $(3 \mathrm{~kg})$ were hand dissected for the experiment on animals, in order to split the testa and kernel fractions. Five diets $(A-E)$ were formulated to provide the same energetic and essential amino acid contents (see Table I):

Table I. Composition and characteristics of the experimental diets.

Composition et caractéristiques des régimes expérimentaux.

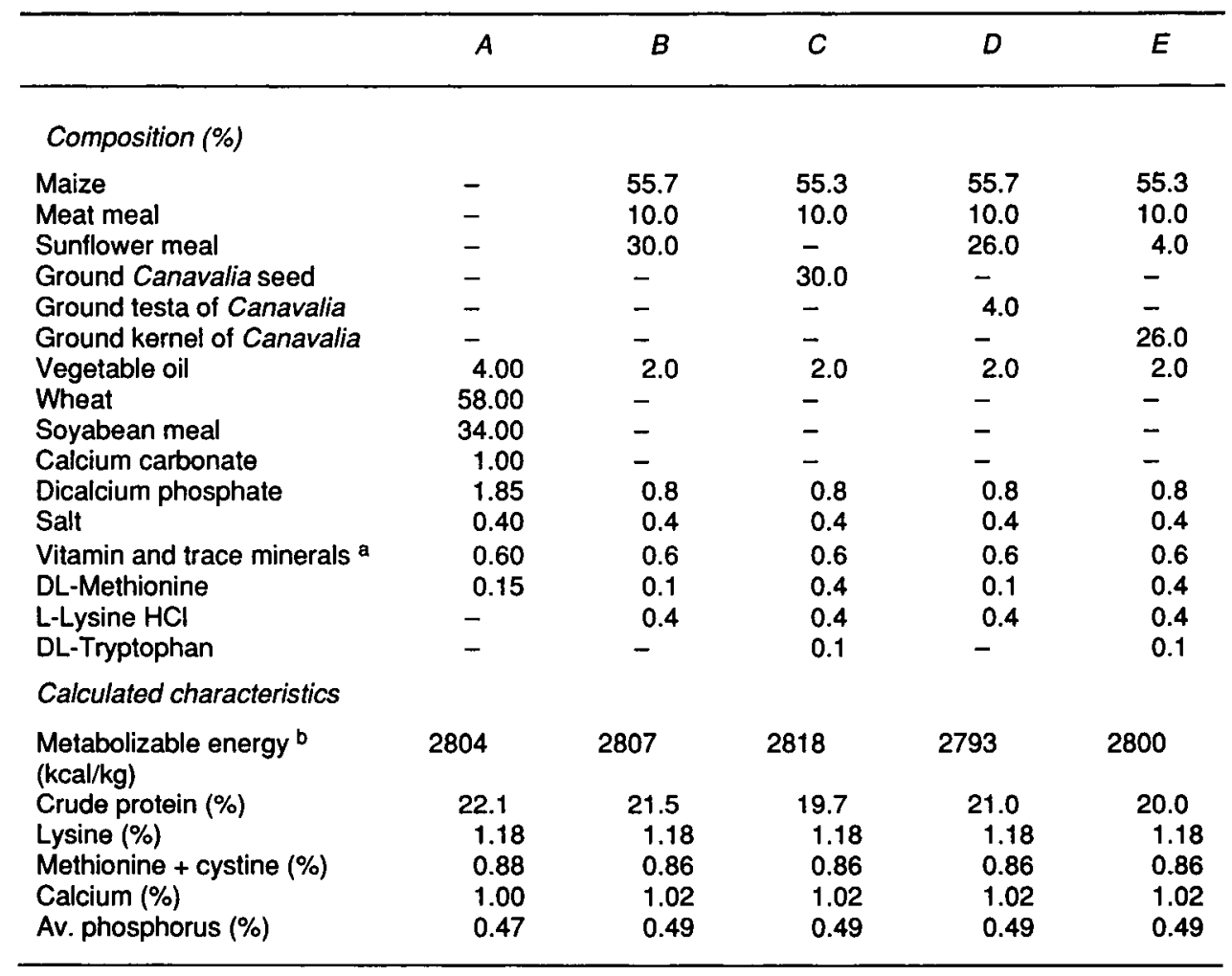

a Providing (100 kg diet): cobalt (88 mg), copper (875 mg), iodin (130 mg), selenium (15 mg), Zinc (10 g), iron (3.5 g), manganese (11 g), Vit. A $\left(10^{6} \mathrm{UU}\right)$, Vit D3 (150 000 IU), Vit $E(1.5 \mathrm{~g})$, Vit $\mathrm{K}(0.5 \mathrm{~g})$, thiamine $(0.05 \mathrm{~g})$, riboflavin $(0.4 \mathrm{~g})$, Ca pantothenate $(0.8 \mathrm{~g})$, Niacin $(2.5 \mathrm{~g})$, pyridoxin $(0.1 \mathrm{~g})$, Vit B12 $(0.8 \mathrm{mg})$, folic acid $(20 \mathrm{mg})$, biotin (10 $\mathrm{mg})$, cholin chloride $(50 \mathrm{~g}), \mathrm{BHT}(12.5 \mathrm{~g})$. These micronutrients are premixed on oat meal (QS $600 \mathrm{~g})$.

b Estimations. 


\section{Diet A}

It was a control wheat/soya diet given from 1 day old;

\section{Diet B}

It was another control diet nutritrionally equivalent to $A$, but formulated with distinct raw materials: maize, meat and bone meal and Sunflower meal (30\%);

\section{Diet C}

Sunflower meal was replaced by $30 \%$ ground Canavalia seed (plus DL-methionine and tryptophan to balance the amino acid content);

\section{Diets $D$ and $E$}

They contained, respectively, the ground testa and kernel fractions of Canavalia seeds, included at the levels corresponding to those of diet $C$ ( $30 \%$ whole seed), using Sunflower meal to adjust the composition up to $100 \%$.

\section{Animals}

One hundred and fifty 1 day-old male chicks of Hubbard strain were allocated to 30 cages of 5 chicks in an environmentally controlled chamber. Three successive periods were tested.

\section{Day 1}

Fifteen cages received ad libitum diet $\mathrm{A}$ and 15 cages were offered ad libitum diet $\mathrm{C}$; food intake was measured after 2,4 and $24 \mathrm{~h}$;

Day 2 to day 14

All chicks received diet A ad libitum;
Day 15 to day 22

Chicks were individually weighed after 1-night starvation and allocated to 9 blocks of 10 individual cages.

Bird selection was based on their live weight in order to have homogenous blocks. Overall variability was slightly decreased by elimination of the smallest and largest birds. The birds from 1 block were homogenous in live weight $( \pm 4 \mathrm{~g}$ ) and the group was composed of 5 chicks coming from the A-fed group (on day 1) and 5 chicks coming from the C-fed group (on day 1). Each chick was offered 1 of the 5 experimental diets ( $A$ to $E$ ) ad libitum, over 7 days. Food intake was measured individually after $30 \mathrm{~min}, 2 \mathrm{~h}, 4 \mathrm{~h}$, $24 h, 4$ days and 7 days after the experiment. Chicks were individually weighed at days 16,19 and 22 (after 1 overnight starvation period for this last control).

The experimental design is a factorial: 2 dayold treatment $\times 5$ diets $\times 9$ individually controlled chicks, which allowed one to test a possible "presensibilisation" effect on the toxicity of $C$. ensiformis. Analysis of variance was followed by Newman and Keuls test for mean comparison.

\section{RESULTS AND DISCUSSION}

\section{Analytical results (Tables II and III)}

The proportion of testa in Canavalia seed $(13.3 \%)$ is very similar to that of Vicia faba beans $(13.0 \%)$. This value is higher than those of Pisum sativum (8.2\%) (Vose et al., 1976) and Glycine max (7.25\%) (Kawamura, 1967) but lower than the hull content of Lupinus (16.5-31.6\%) (Brillouet \& Riochet, 1983). This is important as testa is expected to be of low nutritional value.

The crude protein content $(\mathrm{N} \times 6.25)$ of Canavalia seed $(31.3 \% \mathrm{DM})$ is similar to 
Table II. Proximate composition of canavalia ensiformis seed (\%/DM).

\begin{tabular}{|c|c|c|c|c|c|c|c|c|}
\hline & \multirow{2}{*}{$\begin{array}{c}\text { Kernel } \\
\text { (86.7\%) }\end{array}$} & \multirow{2}{*}{$\begin{array}{c}\text { Testa } \\
\text { (13.3\%) }\end{array}$} & \multirow{2}{*}{$\begin{array}{l}\text { Whole } \\
\text { seed } \\
(100 \%)\end{array}$} & \multicolumn{5}{|c|}{ Previous experiments (whole seed) } \\
\hline & & & & $\begin{array}{l}\text { Mora } \\
\text { (1983) }\end{array}$ & $\begin{array}{l}\text { Vierma } \\
\text { (1984) }\end{array}$ & $\begin{array}{c}\text { Carabano } \\
(1985)\end{array}$ & $\begin{array}{l}\text { Salas } \\
(1985)\end{array}$ & $\begin{array}{c}\text { Bressani } \\
(1987)\end{array}$ \\
\hline $\begin{array}{l}\text { Crude protein } \\
(\mathrm{N} \times 6.25)\end{array}$ & 35.5 & 3.7 & 31.3 & 31.0 & 31.3 & 28.3 & 30.2 & 31.1 \\
\hline Lipids & 4.0 & - & 3.5 & 3.6 & 2.5 & 2.0 & 2.2 & 2.1 \\
\hline Starch & 41.1 & 0.4 & 35.7 & - & - & - & - & - \\
\hline Sucrose & 1.6 & - & 1.4 & - & - & - & - & - \\
\hline $\begin{array}{l}\text { Water-insoluble } \\
\text { cell wall } \\
\text { Water-soluble }\end{array}$ & 11.9 & 73.6 & 20.1 & - & - & - & - & - \\
\hline $\begin{array}{l}\text { non-starch } \\
\text { polysaccharides }\end{array}$ & 0.6 & 8.2 & 1.6 & - & - & - & - & - \\
\hline Crude fibre & - & - & - & - & 11.3 & 15.2 & - & 9.8 \\
\hline Ash & 3.0 & 3.2 & 3.0 & 3.5 & 4.0 & 4.1 & 3.25 & 3.7 \\
\hline Total & 97.7 & 89.1 & 96.6 & - & - & - & - & - \\
\hline
\end{tabular}

Table III. Comparative analysis of the amino acid composition of Canavalia seed, faba bean and soybean protein ( $\mathrm{g}$ of $\mathrm{AA}$ for $16 \mathrm{~g} \mathrm{~N}$ ).

\begin{tabular}{|c|c|c|c|c|}
\hline \multirow{2}{*}{$\begin{array}{l}\text { Amino } \\
\text { Acid }\end{array}$} & \multirow{2}{*}{ Soybean ${ }^{a}$} & \multirow{2}{*}{ Vicia faba ${ }^{a}$} & \multicolumn{2}{|c|}{ Canavalia ensiformis seed } \\
\hline & & & Total & $\begin{array}{l}\text { Canavanin } \\
\text { excluded }^{\mathrm{b}}\end{array}$ \\
\hline $\begin{array}{l}\text { Aspartic acid } \\
\text { Threonine } \\
\text { Serine } \\
\text { Glutamic acid } \\
\text { Glycine } \\
\text { Alanine } \\
\text { Valine } \\
\text { Isoleucine } \\
\text { Leucine } \\
\text { Tyrosine } \\
\text { Phenylalanine } \\
\text { Lysine } \\
\text { Histidine } \\
\text { Arginine } \\
\text { Proline } \\
\text { Cystine } \\
\text { Methionine }\end{array}$ & $\begin{array}{r}11.53 \\
4.04 \\
5.37 \\
16.04 \\
4.10 \\
4.13 \\
4.81 \\
4.69 \\
7.76 \\
4.90 \\
4.70 \\
6.53 \\
2.41 \\
6.92 \\
5.29 \\
1.43 \\
1.34\end{array}$ & $\begin{array}{r}10.25 \\
3.47 \\
5.16 \\
12.60 \\
4.13 \\
3.82 \\
4.74 \\
4.32 \\
7.59 \\
3.28 \\
4.53 \\
6.24 \\
2.41 \\
9.13 \\
4.13 \\
0.98 \\
0.64\end{array}$ & $\begin{array}{l}8.25 \\
3.44 \\
4.38 \\
9.26 \\
3.23 \\
3.34 \\
3.70 \\
3.27 \\
6.64 \\
2.69 \\
3.41 \\
4.45 \\
2.30 \\
4.38 \\
2.77 \\
0.72 \\
0.75\end{array}$ & $\begin{array}{r}10.63 \\
4.43 \\
5.64 \\
11.93 \\
4.16 \\
4.30 \\
4.77 \\
4.21 \\
8.55 \\
3.46 \\
4.39 \\
5.73 \\
2.96 \\
5.64 \\
3.57 \\
0.93 \\
0.97\end{array}$ \\
\hline $\begin{array}{l}\text { Methionine + } \\
\text { Cystine }\end{array}$ & 2.77 & 1.52 & 1.47 & 1.90 \\
\hline Canavanin & 0 & 0 & 11.48 & 0 \\
\hline
\end{tabular}

a Data from Janssen et al., 1979.

b Taking into account the nitrogen content in canavanin; i.e. a protein content of Canavalia seeds of $24.3 \%$ instead of $31.3 \%$ (see text). 
previously published results $(28.3-31.3 \%$, Table II). These protein levels are similar to those reported for Vicia faba (29\%; Lacassagne et al., 1988) and Phaseolus vulgaris (26\%; Fleming, 1981). They are higher than the protein level of Pisum sativum (21\%; Reichert \& MacKenzie, 1982) but lower than those found in Glycine max (44\%; Bianchi et al., 1984) and various lupin species (40\%; Brillouet \& Riochet, 1983). The major part (98.3\%) of the crude protein contained in Canavalia seeds is located in the kernel.

The composition of the protein found for the present sample of $C$. ensiformis was compared to that of Vicia faba and soyabean (Janssen et al., 1979) in Table III. We observed a very low content of the major essential amino acids methionine $(0.75$ $\mathrm{g} / 16 \mathrm{~g} \mathrm{~N})$, cystine $(0.72 \mathrm{~g} / 16 \mathrm{~g} \mathrm{~N})$ and lysine $(4.45 \mathrm{~g} / 16 \mathrm{~g} \mathrm{~N})$. The total sulfurcontaining amino acid (SAA) content in Canavalia was found to be similar to that of Vicia faba (about $1.5 \mathrm{~g} / 16 \mathrm{~g} \mathrm{~N}$ ) and much lower than the concentration of SAA in soyabean. This is characteristic of most proteagenous legume seed. The concentration of lysine is lower than that reported for Vicia faba $(6.24 \mathrm{~g} / 16 \mathrm{~g} \mathrm{~N})$ and soyabean $(6.53 \mathrm{~g} / 16 \mathrm{~g} \mathrm{~N})$. However, this disadvantage needs to be discussed taking into account the very high level of an abnormal free amino acid, canavanin $(11.5 \mathrm{~g} / 16 \mathrm{~g}$ $\mathrm{N}$ ), which tends to reduce proportionally the concentration of all other amino acids when expressed in $\mathrm{g} / 16 \mathrm{~g} \mathrm{~N}$. Canavanin is an analogue of arginine and its toxicity might be related to a possible interference in protein synthesis (Dixon et al., 1983). It is highly soluble and resistant to heat. We are presently working to clarify its mode of action and find some suitable procedures either to eliminate canavanin by genetic selection or by technological treatments on the seed (Vierma, 1984). One specific problem with $C$. ensiformis is the high con- tent of canavanin $(11.48 \mathrm{~g} / 16 \mathrm{~g} \mathrm{~N})$. This analogue of arginine contains 4 atoms of nitrogen in the molecule; i.e. $56 / 176=$ $31.8 \%$ nitrogen instead of $16 \%$ (standard nitrogen content for protein). Taking into account this discrepancy, the useful protein content of Canavalia would be $24.3 \%$ instead of $31.3 \%$ should we subtract the nitrogen content of canavanin. The amino acid profile, with canavanin excluded, and expressed in $\mathrm{g} / 16 \mathrm{~g} \mathrm{~N}$ for a $24.3 \%$ crude protein content in dry matter, becomes very similar to that of Vicia faba (Table III).

The obtained values in our study were close to those published by D'Mello et al. (1985) but differed from the data published by Molina et al. (1974) and by Bressani et al. (1987), who reported higher values for lysine.

Starch represents the main component of Canavalia seed (35.7\%) and thus contributes mainly to its energy value. The apparent metabolisable energy value of the same Canavalia seeds measured in cockerels was found to be $2200 \mathrm{kcal} / \mathrm{kg}$ dry matter and $2800 \mathrm{kcal} / \mathrm{kg}$ dry matter for crude and extruded seeds, respectively (Leon et al., 1986; Picard et al., 1987). Only traces of starch were found in testa. Slightly higher amounts of starch have been previously reported for Vicia faba seed (42\%; Lacassagne et al., 1988) and Pisum sativum seed (47\%; Carré et al., 1987). The sucrose level $(1.4 \%)$ is close to the values found in Vicia faba (1.7\%) and Pisum sativum (2.1\%) (Quemener \& Brillouet, 1983).

According to the very low content of starch and crude protein found in the water-insoluble cell-wall (WICW) isolated from kernel ( 1.5 and $7.4 \%$ respectively) and testa $(0.04$ and $0.4 \%)$, the content of WICW reported in Table II can be considered as an accurate value. The WICW content of Canavalia seed $(20.1 \%)$ is slightly higher than that of Vicia faba (17.4\%; Carré \& Brillouet, 1986) with a higher amount of 
WICW found in the kernel $11.9 \%$ of cellwall in Canavalia kernel versus $7.2 \%$ in Vicia faba kernel; Brillouet \& Carré, 1983). As expected, the WICW content of whole seed is higher than the previously published crude fibre contents, since WICW includes hemicelluloses and pectic substances, in contrast to crude fibre (Carré \& Brillouet, 1989).

A sizeable amount of water-soluble nonstarch polysaccharides (WSNSP) is found in the testa $(8.2 \%)$, and very little in the kernel $(0.6 \%)$. The individual sugar distributions of WSNSP from the kernel (arabinose 39; xylose 6; galactose 23; uronic acids, $32 \%$ of WSNSP) and testa (rhamnose, 18; arabinose, 3; xylose, 3; galactose, 9; glucose, 1 ; uronic acids, $66 \%$ of WSNSP) indicate that these WSNSP are mainly pectic substances.

The amount of anthocyanidins produced from the acidic treatments of cell-walls were found to be undetectable and it could be concluded that seeds of $C$. ensiformis are free of harmful levels of condensed tannins.

The sample of $C$. ensiformis seeds analysed in this study showed a chemical composition quite similar to that of Vicia faba seeds. Accordingly, Canavalia seems to be a potentially reasonable source of starch and protein for monogastric animals, provided that the major toxic constituents of the seeds could be eliminated.

\section{Chick toxicity trial}

\section{Day-old results (see Table IV)}

Young chicks, never fed before, ate significantly less of diet $C$ as compared to $A$, as early as $2 \mathrm{~h}$ after the first distribution of the feed. The food intake of diet $C$ is approximately half that of $\operatorname{diet} A$, and the effect is similar after $24 \mathrm{~h}$. This very early detection did not affect the subsequent performances of the chicks from day 2 to day 14 , once they returned to the control diet $\mathrm{A}$ ad libitum. This early exposure to Canavalia did not at all affect the reaction of the birds to any dietary treatment between day 15 and day 22.

Table IV. Effect of Canavalia on day old chicks and subsequent performances.

\begin{tabular}{|c|c|c|c|c|c|c|}
\hline \multirow{3}{*}{ Diet } & \multicolumn{3}{|c|}{ Day-old } & \multicolumn{3}{|c|}{ Period 2 - 14 days } \\
\hline & \multicolumn{3}{|c|}{ Food intake (g/chick) } & \multirow[t]{2}{*}{ Diet } & \multirow{2}{*}{$\begin{array}{c}\text { Food intake } \\
\text { (g/chick) }\end{array}$} & \multirow{2}{*}{$\begin{array}{l}\text { Live weight } \\
\text { at } 14 \text { days } \\
\text { (g/chick) }\end{array}$} \\
\hline & $0-2 h$ & $0-4 h$ & $0-24 h$ & & & \\
\hline $\begin{array}{l}A \\
C\end{array}$ & $\begin{array}{l}1.22 \pm 0.32 a^{*} \\
0.69 \pm 0.19 b\end{array}$ & $\begin{array}{l}2.71 \pm 0.46 a \\
1.48 \pm 0.34 b\end{array}$ & $\begin{array}{l}7.67 \pm 0.77 a \\
3.33 \pm 0.55 b\end{array}$ & $\begin{array}{l}A \\
A\end{array}$ & $\begin{array}{l}343.6 \pm 14.0 a \\
330.5 \pm 18.9 a\end{array}$ & $\begin{array}{l}258.5 \pm 17.1 \mathrm{a} \\
250.7 \pm 14.6 \mathrm{a}\end{array}$ \\
\hline
\end{tabular}

Averages \pm standard deviation of groups of 5 birds.

* FTest: different letters show significant differences between treatments $(P>0.95)$. 
Table V. Average effects of Canavalia fractions on the growth performances of chicks between 15 and 22 days of age.

\begin{tabular}{|c|c|c|c|c|c|c|}
\hline \multirow[t]{2}{*}{ Diet } & \multicolumn{2}{|c|}{ Live weight (g/chick) } & \multicolumn{4}{|c|}{ Food intake (g/chick) during the test } \\
\hline & 15 days & 22 days & $0-30 \mathrm{~min}$ & $0-2 h$ & $0-4 h$ & $0-7$ days \\
\hline $\begin{array}{l}A \\
B \\
C \\
D \\
E\end{array}$ & $\begin{array}{l}254.4 \pm 16.7 \\
254.5 \pm 16.9 \\
254.9 \pm 16.8 \\
254.9 \pm 17.5 \\
254.3 \pm 15.4\end{array}$ & $\begin{array}{l}476.7 \pm 32.5 \mathrm{a}^{\star} \\
455.4 \pm 31.8 \mathrm{ab} \\
223.6 \pm 19.7 \mathrm{c} \\
438.2 \pm 34.9 \mathrm{~b} \\
227.8 \pm 24.8 \mathrm{c}\end{array}$ & $\begin{array}{l}7.3 \pm 1.2 \mathrm{a} \\
4.3 \pm 1.0 \mathrm{~b} \\
4.5 \pm 1.2 \mathrm{~b} \\
3.8 \pm 1.2 \mathrm{~b} \\
4.8 \pm 1.2 \mathrm{~b}\end{array}$ & $\begin{array}{r}14.6 \pm 2.5 \mathrm{a} \\
12.1 \pm 2.0 \mathrm{~b} \\
7.7 \pm 1.4 \mathrm{c} \\
11.4 \pm 2.2 \mathrm{~b} \\
7.4 \pm 1.6 \mathrm{c}\end{array}$ & $\begin{array}{r}20.8 \pm 3.5 \mathrm{a} \\
20.5 \pm 2.2 \mathrm{a} \\
9.4 \pm 1.7 \mathrm{~b} \\
19.2 \pm 1.8 \mathrm{a} \\
8.4 \pm 1.9 \mathrm{~b}\end{array}$ & $\begin{array}{l}434 \pm 36 a \\
429 \pm 47 a \\
133 \pm 24 b \\
407 \pm 44 a \\
117 \pm 25 b\end{array}$ \\
\hline
\end{tabular}

Averages \pm standard deviation of individuals.

- Newman and Keuls test: means having different letters are significantly different $(P>0.95)$.

\section{5-22 day test (see Table V)}

Because of the complete lack of correlation between day-old exposure and further reactions, only average results for 18 chicks per treatment are shown in Table V. Both the results on growth and food intake clearly demonstrate that all the toxicity of C. ensiformis is located in the kernel and that testa are probably free of any toxicity. The striking similarity of the low performance of birds fed either diet $C$ (full seed) or $E$ (kernel), suggests that most (if not all) of the toxic compounds for chicks are located in the kernel.

Food-intake data (Table V) show that the growing chick ( 15 days old) is able to make a very rapid detection of toxic compounds (between $30 \mathrm{~min}$, and $2 \mathrm{~h}$ ). The comparison of the diets $A$ and $B$ enables one to distinguish between an "effect of surprise when faced with a new feed" (reduction of intake over $30 \mathrm{~min}$, which is equivalent for diets $B$ to $E$ as compared to A) from a toxic effect (0-2 h) which appears for Canavalia seed and kernel diets ( $C$ and $E$ ) between $30 \mathrm{~min}$, and $2 \mathrm{~h}$. Birds fed the non-toxic diets $B$ and $D$ made up a food-intake level similar to that of group $A$ after $30 \mathrm{~min}$.

This experiment suggests that the toxicity of Canavalia seed is mainly located in the kernel. The high proportion of testa (13.3\%) and its high concentration of water-soluble non-starch polysaccharide do not seem to be responsible for the sizeable toxic effect on growth and food intake of chicks under the conditions of this trial. Testa should therefore be removed only if the technological added cost is paid back by the higher nutritive concentration of a kernel meal. However, this treatment cannot alone alleviate or significantly decrease the toxicity of the seed.

Lower food-intake reactions have been mentioned in chickens by D'Mello et al. (1985) and in rats by Wyss and Bickel (1988), receiving Canavalia containing diets. The present work reveals that the kinetics of the food-intake reaction should be taken more into consideration. The foodintake decrease might be the initial cause of the growth depression observed with Canavalia. The exact origin of the rapid food rejection observed in the present experiment remains to be investigated. Lec- 
tins are known to affect food intake and to give nausea in human subjects (Liener, 1986). This might be associated with the high concanavalin A content of Jackbean seeds. The actual tryptophan content of the seeds should also be checked.

Early food intake control in chicks could be a suitable approach for a more systematic determination of the toxic effects of various fractions of jackbean seeds.

\section{ACKNOWLEDGMENTS}

We express our sincere gratitude to Claude Bouchot for his excellent technical assistance. This work was supported by Protinal, Pro Agro, Fondations Mendoza and Polar and Conicit in Venezuela, the French Embassy in Caracas, and the CEFI in France. Their support is greatly appreciated.

\section{REFERENCES}

Bianchi M.P., Silva H.C. \& Braga G.L. (1984) Oligosaccharide content of ten varieties of darkcoated soybeans. J. Agric. Food Chem. 32, 355357

Bergmeyer H.U. \& Bernt E. (1974) In: Methods of Enzymatic Analysis (Bergmeyer H.U., ed.). Vol. 3, 2nd ed., Verlag Chemie, Weinhein, Academic Press, New York and London, 1176-1179

Blakeney A.B., Harris P.J., Henry R.J. \& Stone B.A. (1983) A simple and rapid preparation of alditol acetates of monosaccharide analysis. Carbohydr. Res. 113, 291-299

Blumenkrantz N. \& Asboe-Hansen G. (1973) New method for quantitative determination of uronic acid. Anal. Biochem. 54, 484-489

Boehringer Mannheim (1980) Methods of Enzymatic Food Analysis. Boehringer Mannheim, 6800 Mannheim 31, F.R.G.
Bressani R., Brenes R.G., Garcia A. \& Elias L.G. (1987) Chemical composition, amino acid content and protein quality of Canavalia spp. seeds. J. Sci. Food Agric. 40, 17-23

Brillouet J.M. \& Carré B. (1983) Composition of cell walls from cotyledons of Pisum sativum, Vicia faba and Glycine max. Phytochemistry 22. 841-847

Brillouet J.M. \& Riochet D. (1983) Cell wall polysaccharides and lignin in cotyledons and hulls of seeds from various lupin (Lupinus L.) species. $J$. Sci. Food Agric. 34, 861-868

Carabano J., Mariano D., de Seidl D., Hasegawa M. \& Kodaira M. (1985) Posibilidades de la extrusion como tratamiento de la Canavalia ensiformis para uso en raciones para eves. Proc. Primer Congreso Nacional de Nutricion, Caracas

Carré B. \& Brillouet J.M. (1986) Yield and composition of cell wall residues isolated from various feedstuffs used for non-ruminant farm animals. J. Sci. Food Agric. 37, 341-351

Carré B. \& Brillouet J.M. (1989) Determination of water-insoluble cell walls in feeds : Interlaboratory study. J. Assoc. Off. Anal. Chem. 72, 463467

Carré B., Escartin R., Melcion J.P., Champ M., Roux G. \& Leclercq B. (1987) Effect of pelleting and associations with maize or wheat on the nutritive value of smooth pea (Pisum sativum) seeds in adult cockerels. Br. Poult. Sci. 28, 219229

Carré B., Prévotel B. \& Leclercq B. (1984) Cell wall content as a predictor of metabolisable energy value of poultry feedingstuffs. Br. Poult. Sci. 25, 561-572

Delpech P., Guezel M., Leclercq B. \& Kahane E. (1966) Méthode d'extraction des lipides en continu et à chaud par le mélange azéotrope : benzène-éthanol-eau. Rev. Fr. Corps Gras 10, 1-6 Dixon R.M., Escobar A., Montilla J., Viera J., Carabano J., Risso J., Parra R. \& Preston T.R. (1983) Canavalia ensiformis: a legume for the tropics. In: Proc. Australian Conf. Animal Prod. Townsville, Australia

D'Mello O.P.F., Acamovic T. \& Walker A.G. (1985) Nutritive value of Jack beans (Canavalia ensiformis) for the young chicks. Trop. Agric. (Trinidad), 62 (2), 145-150

Fleming S.E. (1981) A study of relationships between flatus potential and carbohydrate distribution in legume seeds. J. Food. Sci. 46, 794-797 
Folch J., Lees H. \& Sloane-Sranley G.H. (1957) A simple method for the isolation and purification of total lipids from animal tissues. J. Biol. Chem. 226, 497-509

Hakansson J. (1974) Factors affecting the digestibility of fats and fatty acids in chicks and hens. Swed. J. Agric. Res. 4, 33-47

Janssen W.M.M.A., Terpstra K., Beeking F.F.E., Bisaisky A.J.N. (1979) Feeding Values for Poultry. 2nd edn., Spelderholt Institute, Beekbergen, The Netherlands

Kawamura S. (1967) Quantitative paper chromatography of sugars of the cotyledon, hull and hypocotyl of soybeans of selected varieties. $\mathrm{Ka}$ gawa University, Fac. Tech. Bull. 15, 117-131

Lacassagne L., Francesh M., Carré B. \& Melcion J.P. (1988) Utilization of faba bean (Vicia faba) protein, starch and energy by young chicks. Effect of pelleting seeds from tannincontaining and tannin-free cultivars. Anim. Feed Sci. Technol. 20, 59-68

Leon A., Picard M., Parra R., Montilla J.J. \& Vargas R. (1986) Determinacion de la energia metabolizable aparente y verdadera de los granos de Canavalia ensiformis. Proc. 35 Convencion Anual ASOVAC, Valencia, Venezuela, 1621 Nov. p. 33

Liener I.E. (1986) Nutritional significance of lectins in the diet. In: The Lectins (Liener I.E., Sharon N. \& Goldstein I.J., eds.). Academic Press, New York, pp. 527-552

Molina M.R. Argueta C.E. \& Bressani R. (1974) Extraction of nitrogenous constituents from the Jack bean (Canavalia ensiformis). J. Agric. Food Chem. 22 (2), 309-312
Mora M. (1983) Canavalia ensiformis. Uso en rumiantes. Tesis de Grado. Facultad de Agronomia UCV, Maracay, Venezuela

Picard M., Leon A., Angulo I., Montilla J.J., Parra R. \& Vargas R. (1987) Recientes avances del programa de investigaciones VenezolanoFrances en Avicultura. Proc. 2 Congreso FENAVI, Caraballeda, Venezuela

Quemener B., Brillouet J.M. (1983) Ciceritol, a pinitol digalactoside from seeds of chick pea, lentil and white lupin. Phytochemistry 22, 17451751

Reichert R.D. \& MacKenzie S.L. (1982) Composition of peas (Pisum sativum) varying widely in protein content. J. Agric. Food Chem. 30, 312317

Salas P. (1985) Evaluacion nutricional de cinco cultivars de Canavalia ensiformis incorporadas en raciones para aves en crecimiento. Tesis de Grado, Facultad de Agronomia UCV, Maracay, Venezuela

Vierma C. (1984) Efecto de varios tratamiento sobre los factors anti-nutricionales de Canavalia ensiformis incluida en dietas para pollos en crecimiento. Tesis de Grado, Facultad de Ciencias Veterinarias U.C.V., Maracay, Venezuela

Vose J.R., Bastarrechea M.J., Gorin P.A.G., Fin Layson A.J. \& Youngs C.G. (1976) Air classification of field peas and horse bean flours: Chemical studies of starch and protein fractions. $\mathrm{Ce}$ real Chem. 53, 928-936

Wyss U. \& Bickel H. (1988) Ripe beans of Canavalia ensiformis (Jackbean) as feed ingredient for monogastric animals. Anim. Feed Sci. Technol. 20, 325-326 